\title{
Agile methodology perceived success and its use: The moderating effect of perceived compatibility
}

\author{
Tawanda Blessing Chiyangwa ${ }^{a}$, Ernest Mnkandla ${ }^{a}$ \\ ${ }^{\text {a }}$ School of Computing, University of South Africa, South Africa
}

\begin{abstract}
This article investigated the moderating effect of the perceived compatibility of agile methodologies in determining the actual success of a methodology. The researchers conceptualised the agile methodology perceived success by using cost, scope, time and quality to complete the project. The researchers further hypothesised that perceived compatibility has moderating effects towards agile methodology perceived success and its use. The theoretical framework was evaluated by means of data collected from IT professionals $(n=230)$. The objective of the study was to determine how agile methodology use and perceived compatibility influence agile methodology perceived success in South Africa. A survey was conducted among IT professionals and the results analysed using statistical methods. The results showed perceived compatibility to have a moderating effect towards agile methodology use, time and cost. Nevertheless, there was a lack of moderating effect of perceived compatibility with regard to agile methodology use and perceived quality, and agile methodology use and perceived scope. The results of this study formulate a comprehensive model that could provide a set of guidelines for agile methodology use to the agile methodology communities and other IT professionals in South Africa.
\end{abstract}

Keywords: agile methodology, perceived compatibility, software projects, theory of reasoned action, unified theory of acceptance, use of technology

Categories: • Applied computing $\sim$ Software development $\bullet$ Applied computing $\sim$ Project management

Email:

Tawanda Blessing Chiyangwa chiyatb@unisa.ac.za (CORRESPONDING),

Ernest Mnkandla mnkane@unisa.ac.za
Article history:

Received: 29 Oct 2017

Accepted: 10 Oct 2018

Available online: 30 Nov 2018

\section{INTRODUCTION}

It has long been understood that a large portion of software development projects fail. Recent estimates put the approximate figures at $65 \%$ of software development projects failing to meet their timeframes and incurring high costs to the organisations (Bossini \& Fernández, 2013). Companies therefore continue to spend a lot of money in agile development process adoption and expect completion of the projects on time and within budget (Ambler, 2009; Chow \& Cao, 2008). However,

Chiyangwa, T. and Mnkandla, E. (2018). Agile methodology perceived success and its use: The moderating effect of perceived compatibility. South African Computer Journal 30(2), 1-16. https://doi.org/10.18489/sacj.v30i2.554 Copyright (C) the author(s); published under a Creative Commons NonCommercial 4.0 License (CC BY-NC 4.0). $S A C J$ is a publication of the South African Institute of Computer Scientists and Information Technologists. ISSN 1015-7999 (print) ISSN 2313-7835 (online). 
many software development projects, including those adopting agile methodologies, continue to incur high costs and are completed beyond the initially agreed time frames (Dingsøyr, Dybå \& Abrahamsson, 2008).

The selection of inappropriate methodologies to manage software development projects contributes to the failure of these projects (Bossini \& Fernández, 2013; Stankovic, Nikolic, Djordjevic \& Cao, 2013). Currently, there is confusion over which software development processes to choose in different circumstances. Consequently, there is a need for software development project managers to understand when it is appropriate to use agile methodologies and when traditional methodologies are applicable (Hartung \& Knapp, 2014; Taylor \& Todd, 1995).

According to Boehm and Turner (2004), V. Bullen and F. Rockart (1981), Cockburn and Highsmith (2001), Cohn (2010), Cohn and Ford (2003), Dingsøyr et al. (2008), Misra, Kumar and Kumar (2009), Nerur, Mahapatra and Mangalaraj (2005), Reel (1999) and Straub, Boudreau and Gefen (2004), there are several critical success factors (such as top management support and training, co-location of the whole team and facilities with proper agile-style work environments, etc.) that are required for agile software development projects to be successful. Furthermore, a successful project needs devoted people and sponsors who are directly involved in the software project and individuals who are excited about putting everything into practice, confronting resistance and encouraging the management and employees towards the organisation's vision and mission through communication (bin Ahlan et al., 2013; Chow \& Cao, 2008; Cohn \& Ford, 2003; Dybå \& Dingsøyr, 2009; Joseph, 2014).

Despite agile professionals having identified several critical success factors, agile software projects still fail (Chow \& Cao, 2008; Joseph, 2014). Marnewick (2012) discovered that $12 \%$ of information and communication technology (ICT) software projects failed in South Africa in 2011, which means that approximately R114 billion was wasted in 2011. Joseph (2014) forecasted that the increase in overspending in ICT software projects would rise to approximately R150 billion in 2016, which implied that more than R18 billion would also be wasted in 2016 in South Africa, based on the 2011 failure rate calculated in the same study.

Therefore, there is a need to model the critical factors that influence the success of software projects that use agile methodologies to avoid a waste of money, time and organisational resources. Unfortunately, not all the critical success factors that affect agile software projects can be addressed at once. However, modelling the complexities of software development through new probabilistic methods presents a positive way forward.

There are some inconclusive findings with regard to the role of agile methodologies for improving project success as outcomes in prior literature (Ambler, 2009; Chow \& Cao, 2008; Dingsøyr et al., 2008; Joseph, 2014). To deal with this limitation, we address the following research question in this paper:

How does agile methodology use and perceived compatibility, influence agile methodology use outcomes (perceived success)?

Perceived compatibility is "the degree to which an innovation is perceived as being consistent with the existing values, needs and past experiences of potential adopters" (Moore \& Benbasat, 1991). 
The remainder of this article is organised as follows: in Section 2 the authors present the background literature and theoretical development of the study. Section 3 follows with a discussion on the research methodology. Section 4 discusses the results of the study and finally, Section 5 concludes the study and mentions future research for this study.

\section{LITERATURE REVIEW AND THEORY DEVELOPMENT}

\subsection{Agile methodology perceived success}

Existing theories have mostly been used to examine the usage and acceptance of information technology (IT) tools. Diffusion of Innovation (DOI) theory, Theory of Reasoned Action (TRA), Theory of Planned Behaviour (TPB), Unified Theory of Acceptance and Use of Technology (UTAUT) and Technology Acceptance Model (TAM) have been widely used for examining an individual's intentions to adopt IT innovations, such as the World Wide Web and Microsoft Office spreadsheets (Chow \& Cao, 2008; Iivari \& Huisman, 2007).

Several studies on agile methodologies are based on the practical use of agile methodologies and their costs and benefits, with a couple of studies on the factors affecting the acceptance of agile methodologies as part of their success (Chow \& Cao, 2008; Misra et al., 2009). These studies have used the existing theories to explore the use and acceptance of agile methodologies.

Chow and Cao (2008) performed an initial investigation into individual usage and acceptance of agile software development projects by using constructs from TAM, TRA, TPB, DOI and UTAUT. In their research, the perceived usefulness and perceived ease of use scales were shown, in general, to be reliable measures in the agile software development context. Misra et al. (2009) adapted actual behavioural constructs from TAM, TRA, TPB, DOI and UTAUT to determine critical success factors for agile software development projects. Further, team environment has been found to be an important factor that would affect the agile professional's perceptions of agile software development (Chow \& Cao, 2008; Iivari \& Huisman, 2007). Indeed, few studies have gone beyond use to investigate the factors associated with agile methodology use and the perceived success.

These studies suggest a number of organisational, people, process, culture, technology and project factors that are crucial to the successful assimilation of the agile methodologies usage. These studies have not taken characteristics of perceived compatibility of individuals towards cost, quality, scope and time into consideration.

Although the use of a theoretical framework, for example, technology of acceptance model, excludes perceived success factors of the agile methodology use as a construct, Delone and McLean (2003) explained a direct influence between perceived success factors of the agile methodology use and overall paybacks. This effect has been comprehensively confirmed in systematic literature (Delone \& McLean, 2003). The causal effects suggest that when IT professionals take part in the agile methodology usage, less cost to the company is involved, less optimum time to accomplish the project is involved and appropriate scope of the project is achieved, as perceived success factors of agile methodology use (Chow \& Cao, 2008).

Even though the relationships between the agile methodology use and its perceived success 
were discovered as strong in several previous literatures (Chow \& Cao, 2008; Joseph, 2014), some research studies described a very weak influence in the agile methodology framework (Chow \& Cao, 2008). These inconsistent results lead us to examine the influence further. The researchers in this study suggest that compatibility moderates the direct influences. Therefore, this research study regards cost of the projects, quality of the projects, scope of the projects and time taken to complete the projects as perceived success factors.

\subsection{Perceived compatibility as a moderator}

Perceived compatibility is "the degree to which an innovation is perceived as being consistent with the existing values, needs and past experiences of potential adopters" (Moore \& Benbasat, 1991, p. 195). Perceived compatibility has vastly and frequently utilised psychology and IT to find the impact it has towards perceived intention and perceived success (Venkatesh, Morris, Davis \& Davis, 2003) and perceived usefulness (Venkatesh \& Davis, 2000). Perceived compatibility normally has significant impact on perceived intention and perceived success of software development projects (Taylor \& Todd, 1995). Perceived compatibility had been used in research publications with different names with the same meaning such as task-technology fit and job-relevance (Goodhue \& Thompson, 1995; Venkatesh \& Davis, 2000).

The following four criteria used to determine the perceived success of agile software development projects are based on Chow and Cao (2008) and Misra et al. (2009),

- Quality (delivering a good product or project outcome)

- Time (delivering on time)

- Cost (delivering within the estimated cost and effort)

- Scope (meeting all requirements and objectives)

Better quality software projects can be attained if there is more budget and time at disposal. However, project managers are usually constrained with respect to time, budget and the quality of the software the project is expected to deliver. The same expectations are still effective for software projects using agile methodologies (Chow \& Cao, 2008; Misra et al., 2009). Hence, any software project using agile practices would be considered succeful if it can deliver better quality software in a shorter time and lower budget than traditional software development practices (Misra et al., 2009).

This study proposed that perceived compatibility might have direct or indirect influence beyond perceived ease of use, perceived usefulness and perceived intentions, particularly on the agile methodology use towards perceived success constructs. In most cases, if IT professionals do not have a choice not to use particular technology, they are often likely to implement the technology to accomplish their job (Goodhue \& Thompson, 1995). Thus we hypothesise that:

H1. Perceived compatibility has direct or indirect influence between the agile methodology use and cost of the projects. 
H2. Perceived compatibility has direct or indirect influence between the agile methodology use and time to complete the projects.

H3. Perceived compatibility has direct or indirect influence between the agile methodology use and scope of the projects.

H4. Perceived compatibility has direct or indirect influence between the agile methodology use and quality of the projects.

The theoretical framework is clearly shown in Figure 1 and definitions of constructs are clearly illustrated in Table 1.

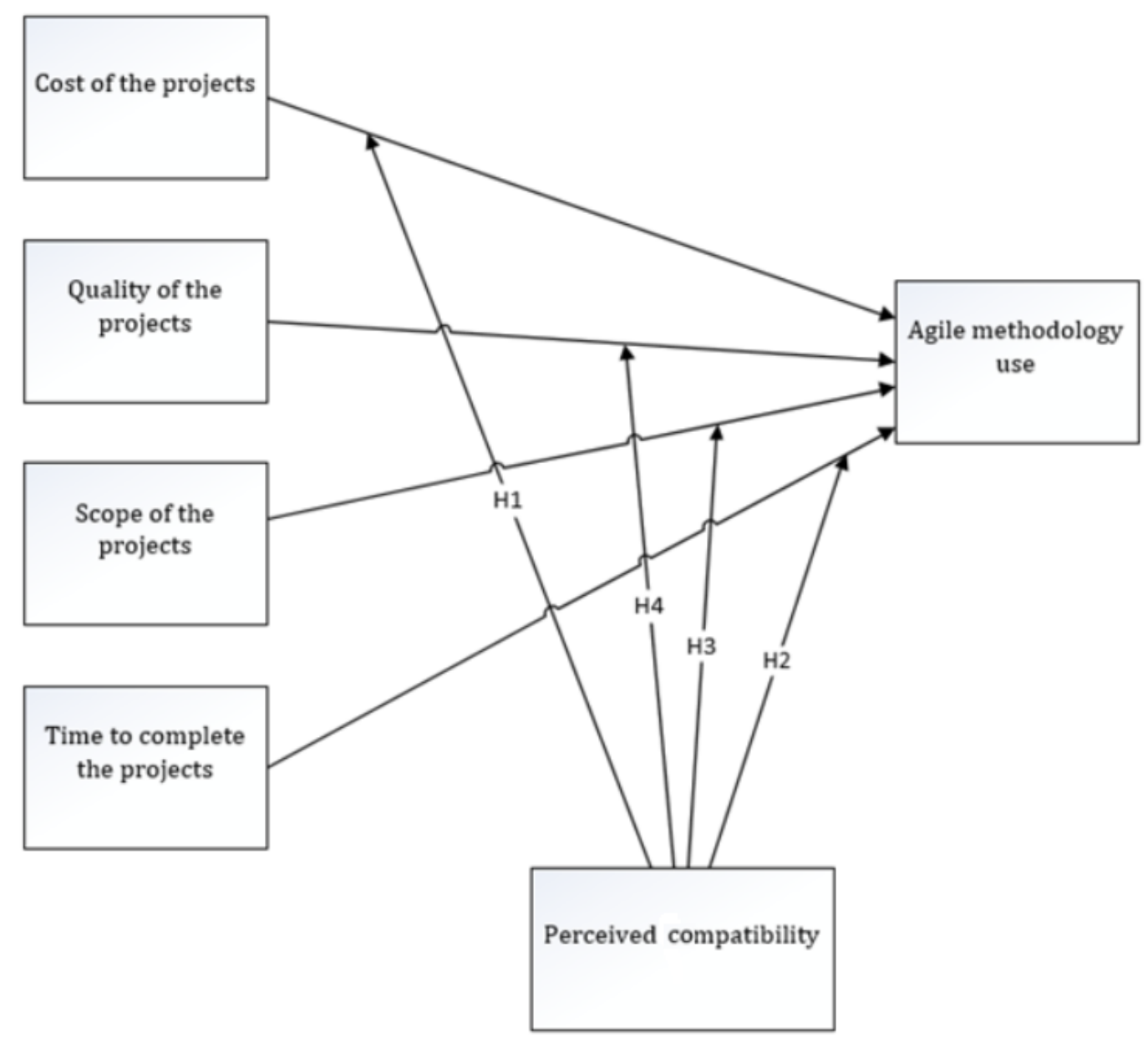

Figure 1: Research model illustrating the hypotheses and their relationship with cost, quality, scope and time to complete the project 
Table 1: Definitions of the constructs (adopted as direct definition of the constructs from Chow and Cao (2008), Islam (2016), and Moore and Benbasat (1991))

\begin{tabular}{|c|c|}
\hline Construct & Definition \\
\hline Perceived compatibility & $\begin{array}{l}\text { The degree to which the agile methodology is perceived as } \\
\text { being consistent with the existing values, needs and } \\
\text { experiences of IT professionals }\end{array}$ \\
\hline Agile methodology use & $\begin{array}{l}\text { User perception regarding their amount of the agile } \\
\text { methodology usage }\end{array}$ \\
\hline Perceived cost of the projects & $\begin{array}{l}\text { User perception of the extent to which they believe the agile } \\
\text { methodology usage will assist their cost savings of the } \\
\text { projects }\end{array}$ \\
\hline $\begin{array}{l}\text { Perceived quality of the } \\
\text { projects }\end{array}$ & $\begin{array}{l}\text { User perception of the extent to which they believe the agile } \\
\text { methodology usage will assist them in the quality of the } \\
\text { software projects }\end{array}$ \\
\hline Perceived scope of the projects & $\begin{array}{l}\text { User perception of the extent to which they believe the agile } \\
\text { methodology usage will assist them in the scope of the } \\
\text { software projects }\end{array}$ \\
\hline $\begin{array}{l}\text { Perceived time of completion } \\
\text { of the projects }\end{array}$ & $\begin{array}{l}\text { User perception of the extent to which they believe the agile } \\
\text { methodology usage will assist them in completing software } \\
\text { projects in time }\end{array}$ \\
\hline
\end{tabular}

\section{METHODOLOGY}

The study used quantitative methods of collecting data.

\subsection{Questionnaire development}

A survey was done by using a structured questionnaire to collect data which relates to the decision variables to be measured. The target sample of population was IT professionals who use the agile methodology in their daily activities of their work. A questionnaire was used to discover IT professionals' perceptions in line with Scrum usage experience in software development projects.

The Likert scale was used to measure the research instrument of the decision variable ranging from "strongly agree (5)" to "strongly disagree (1)". Chow and Cao (2008), Islam (2016) and Misra et al. (2009) questionnaires were adopted for this research study, with minor alterations in wording, showing the agile methodology use and success factors of the projects. The measurement decision variables of perceived compatibility and agile methodology implementation were adapted from Chow and Cao (2008) and Larsen, Sørebø and Sørebø (2009), appropriately. The items for determining perceived cost, quality, scope of the project and time to complete the projects were adopted from Misra et al. (2009).

A pilot test was done, and generally, the IT professionals showed easiness of completing the 
research instrument, which was the questionnaire. Several ideas and changes to be made were noted and the research instrument was corrected to improve its feasibility for this study. Questions in the questionnaire were randomised to avoid survey bias. This study used Harman's one factor test to avoid common method bias (Straub et al., 2004).

\subsection{Study participants and procedure}

The current research was done in South African companies that use Scrum methodology. An online survey was utilised to collect responses from the IT professionals in the organisations who practise Scrum methodology. The LinkedIn website was used to obtain company e-mail addresses of IT employees who were the target population of the sample. A total of 920 e-mail invitations were sent to randomly selected IT professionals of the companies. The research was carried out for two weeks. Twenty-five per cent of the response rate was achieved resulting in 230 responses. Characteristics of the sample demographics are presented in table 2. Only IT professional with 5 years' experience were considered in this research study.

Table 2: Demographic information

\begin{tabular}{lcrr}
\hline Factors & & Frequency & Percentage \\
\hline & Gender & & \\
Male & & 148 & 64.3 \\
Female & Age (years) & 82 & 35.7 \\
\hline & & 13 & \\
$<30$ & & 57 & 5.7 \\
$31-35$ & 56 & 24.8 \\
$36-40$ & & 24.3 \\
$41-45$ & & 37 & 37.8 \\
$>45$ & Experience (years) & 17 & 7.4 \\
\hline & & 0 & \\
$<5$ & & 57 & 0 \\
$5-8$ & & 115 & 50.8 \\
$9-10$ & 58 & 25.2 \\
$>10$ & Role & & \\
\hline & & 131 & 57.0 \\
Software developers / Agile team members & 70 & 30.4 \\
Scrum master & & 29 & 12.6 \\
Team leader & & 230 & 100 \\
\hline Total & &
\end{tabular}




\subsection{Statistical analysis}

The Partial Least Square (PLS) test was formulated by an econometrician whose name was Herman Wold (Barclay, Higgins \& Thompson, 1995; Chin, 1998; Wold, 2006). The proposed hypotheses were evaluated using Smart Partial Least Square (SPLS) version 3.2.7. SPLS 3.2.7 was selected due to its suitablity for small sample sizes and the normal distribution data set which was in line with the research results. Its path models are normally measured by two equations, namely, the structural model and measurement model.

The constructs used for this research (as shown in Table 1) are linked to the individual questions per construct as shown in Table 3.

Internal consistency reliability was used and the composite reliability (CR) of each construct exceeded the threshold value of 0.7 as shown in Table 3 (Dion, 2008; Nunnally, 1978). As illustrated in Table 3, convergent validity used the standards suggested by Fornell and Larcker (1981) to assess the measuring model. The average variance extracted (AVE) of every construct exceed 0.5 as recommended by Fornell and Larcker. Also, the discriminant validity value of the square root of the average variance extracted exceeded the correlation between the measurements suggested by Segars and Grover (1993). A measurement model had indicator reliability of each item's loading above the threshold of 0.7 as suggested by Fornell and Larcker.

The discriminant validity value of the square root of the average variance extracted exceeded the off-diagonal elements in their corresponding row and column as shown in Table 4.

The cross loading results showed that the assessments of the measurement model's discriminant validity were met with a threshold value above 0.7 as shown in Table 5 . 
Table 3: Constructs' items, mean and internal consistencies

\begin{tabular}{|c|c|c|c|c|}
\hline Category & Success factors & Mean & Std & Loading \\
\hline $\begin{array}{l}\text { Perceived } \\
\text { compatibility }\end{array}$ & $\begin{array}{l}P C 1: \text { Agile methodology use is compatible with most aspects } \\
\text { of my work style. }\end{array}$ & 4.00 & 1.21 & 0.83 \\
\hline $\begin{array}{l}(C R=0.82 \\
A V E=0.83)\end{array}$ & $\begin{array}{l}\text { PC2: Using agile methodology fits with the way I like to } \\
\text { work }\end{array}$ & 4.04 & 1.13 & 0.86 \\
\hline \multirow{3}{*}{$\begin{array}{l}\text { Quality of the } \\
\text { project } \\
(C R=0.78 \\
A V E=0.78)\end{array}$} & $\begin{array}{l}\text { QP1: The existence of an agile-friendly project team envir- } \\
\text { onment delivered a better product than in one which was } \\
\text { not. }\end{array}$ & 3.89 & 1.14 & 0.82 \\
\hline & $\begin{array}{l}\text { QP2: The practice of agile project management process de- } \\
\text { livered a better product than one which did not practice. }\end{array}$ & 3.95 & 1.18 & 0.81 \\
\hline & $\begin{array}{l}\text { QP3: The practice of agile software engineering techniques } \\
\text { delivered a better product than one which did not practice. }\end{array}$ & 3.88 & 1.21 & 0.77 \\
\hline \multirow{3}{*}{$\begin{array}{l}\text { Cost of the } \\
\text { project } \\
(C R=0.80 \\
A V E=0.82)\end{array}$} & $\begin{array}{l}S P 1: \text { Project type being of variable scope with emergent } \\
\text { requirements }\end{array}$ & 3.56 & 1.26 & 0.76 \\
\hline & $\begin{array}{l}S P 2 \text { : Having a stronger customer involvement meets all } \\
\text { requirements and objectives, leading to a better product than } \\
\text { in one which did not have. }\end{array}$ & 3.64 & 1.10 & 0.80 \\
\hline & $\begin{array}{l}S P 3: \text { The execution of correct delivery strategy meets all } \\
\text { requirements and objectives, leading to a better product than } \\
\text { in one which did not execute. }\end{array}$ & 3.63 & 1.26 & 0.82 \\
\hline \multirow{3}{*}{$\begin{array}{l}\text { Cost of the } \\
\text { project } \\
(C R=0.80 \\
A V E=0.82)\end{array}$} & $\begin{array}{l}C P 1: \text { The project with up-front cost evaluation was done to } \\
\text { reduce cost. }\end{array}$ & 4.37 & 1.24 & 0.90 \\
\hline & $\begin{array}{l}C P 2 \text { : People and agile teams were placed physically closer } \\
\text { to reduce the cost of moving information between them. }\end{array}$ & 4.32 & 1.18 & 0.91 \\
\hline & $\begin{array}{l}\text { CP3: Replace documents with talking in person and at white- } \\
\text { boards to reduce cost of moving information between people } \\
\text { and agile teams. }\end{array}$ & 4.27 & 1.33 & 0.90 \\
\hline \multirow{3}{*}{$\begin{array}{l}\text { Time of } \\
\text { completion of } \\
\text { the project } \\
(C R=0.83 \\
A V E=0.88)\end{array}$} & $\begin{array}{l}\text { TC1: The functionality was delivered in a more timely man- } \\
\text { ner in a project which is managed using agile principles than } \\
\text { in one which was not. }\end{array}$ & 4.79 & 1.29 & 0.91 \\
\hline & $\begin{array}{l}\text { TC2: The correct integration and testing was done in a more } \\
\text { timely manner in a project which is managed using agile } \\
\text { principles than in one which was not. }\end{array}$ & 4.75 & 1.37 & 0.90 \\
\hline & $\begin{array}{l}\text { TC3: Appropriate technical training was done in a more } \\
\text { timely manner in a project which is managed using agile } \\
\text { principles than in one which was not. }\end{array}$ & 4.73 & 1.25 & 0.94 \\
\hline $\begin{array}{l}\text { Agile } \\
\text { methodology }\end{array}$ & $\begin{array}{l}A M 1: \text { I am currently using the agile methodology at my work } \\
\text { place. }\end{array}$ & 4.88 & 1.39 & 0.92 \\
\hline $\begin{array}{l}\text { use }(C R=0.87 \\
A V E=0.91)\end{array}$ & $\begin{array}{l}\text { AM2: I have used the agile methodology in the past at my } \\
\text { work place. }\end{array}$ & 4.86 & 1.44 & 0.91 \\
\hline
\end{tabular}


Table 4: Correlation among variables and square root of average variance extracted

\begin{tabular}{lrrrrrr}
\hline & $(1)$ & $(2)$ & (3) & (4) & (5) & (6) \\
\hline Cost of the project (1) & 1.00 & & & & & \\
Perceived compatibility (2) & 0.55 & 0.85 & & & & \\
Scope of the project (3) & 0.11 & 0.54 & 0.84 & & & \\
Quality of the project (4) & 0.32 & 0.48 & 0.40 & 0.83 & & \\
The agile methodology use (5) & 0.21 & 0.42 & 0.37 & 0.44 & 0.82 & \\
Time of completion of the project (6) & 0.16 & 0.64 & 0.61 & 0.42 & 0.61 & 0.82 \\
\hline
\end{tabular}

Table 5: Factor analysis results

\begin{tabular}{|c|c|c|c|c|c|c|}
\hline & Perceived compatibility & Quality & Scope & Cost & Time & Agile methodology use \\
\hline$P C 1$ & 0.83 & & & & & \\
\hline$P C 2$ & 0.84 & & & & & \\
\hline$P C 3$ & 0.86 & & & & & \\
\hline$Q P 1$ & & 0.82 & & & & \\
\hline$Q P 2$ & & 0.81 & & & & \\
\hline$Q P 3$ & & 0.77 & & & & \\
\hline$S P 1$ & & & 0.76 & & & \\
\hline$S P 2$ & & & 0.80 & & & \\
\hline$S P 3$ & & & 0.82 & & & \\
\hline$C P 1$ & & & & 0.90 & & \\
\hline$C P 2$ & & & & 0.91 & & \\
\hline$C P 3$ & & & & 0.90 & & \\
\hline$T C 1$ & & & & & 0.91 & \\
\hline TC2 & & & & & 0.90 & \\
\hline TC3 & & & & & 0.94 & \\
\hline$\overline{A M 1}$ & & & & & & 0.92 \\
\hline$A M 2$ & & & & & & 0.91 \\
\hline
\end{tabular}




\section{DISCUSSION OF RESULTS}

Multicollinearity (which describes the high correlation among the explanatory decision variables that prevents their effects from being analysed) was tested (Cheung \& Rensvold, 2002). Hartung and Knapp (2014) suggested that the presence of multicollinearity makes it problematic to evaluate the influence of unidentified parameters giving significant errors to minor changes in data. Thus, this would lead to high significant standard errors with a high correlation coefficient that generates a value of R-squared close to 1 or -1 (Byrne, 2016). This was examined by comparing the R-squared to verify whether it was near \pm 1 . The assumption of multicollinearity was not violated in this study, implying that R-squared coefficients were acceptable as not violating multicollinearity. The other assumptions such as outliers, tolerance, homoscedasticity, scatter plot, normality and linearity were tested. The assumptions of outliers, tolerance, homoscedasticity, scatter plot, normality and linearity would not be violated in this study.

The structural equation model of this research shows the concurrent test of the psychometric properties of the model and analyses the strength and direction of the causal effects of the model. The R-squared values signify the value of variance explained by the independent constructs towards dependent constructs. Table 6 shows the output of the test of the hypothesised model. Perceived compatibility has significant influence on both the perceived cost of the projects and completion time of the projects. Nevertheless, it had a non-significant effect on the quality and scope of the software projects. The agile methodology use had significant effects on all the outcome constructs, namely, perceived cost of the projects, perceived scope of the projects, perceived quality of the projects and perceived time to complete the projects. The explained R-squared values were $0.34,0.56,0.48$ and 0.36. The R-squared values were statistically significant because they had p-values less than five percent.

As illustrated in Table 6, the interaction term of the agile methodology use and perceived compatibility is significant $(\beta=0.39, p<0.001)$ in evaluating the cost of the projects. The cost of software projects can be considered to be the second highest predictor of perceived success. A nested F-test showed that the variance explained was also mathematically significant, $0.34(F(1,215)=$ $42.11, p<0.001$ ) indicating that adding perceived compatibility as a moderating term improves the R-squared for cost of the projects.

The Beta value for time of completion of the projects was 0.45 , making it the largest contributor to the research model, thus the largest predictor to use agile methodology for the success completion for software projects as shown in Tables 6 and 7.

However, the interaction terms had a non-significant impact or influence on both perceived scope $(\beta=.03, p>0.05)$ and perceived quality of the projects $(\beta=.01, p>0.05)$. Tables 6 and 7 summarised the results from hypotheses testing. 
Table 6: PLS results

\begin{tabular}{|c|c|c|c|c|c|c|c|c|}
\hline \multirow[t]{2}{*}{ Determinants } & \multicolumn{2}{|c|}{$\begin{array}{l}\text { Predicting } \\
\text { perceived cost } \\
\text { of the project }\end{array}$} & \multicolumn{2}{|c|}{$\begin{array}{l}\text { Predicting } \\
\text { perceived } \\
\text { quality of the } \\
\text { project }\end{array}$} & \multicolumn{2}{|c|}{$\begin{array}{l}\text { Predicting } \\
\text { perceived scope } \\
\text { of the project }\end{array}$} & \multicolumn{2}{|c|}{$\begin{array}{l}\text { Predicting } \\
\text { perceived time } \\
\text { completion of } \\
\text { the project }\end{array}$} \\
\hline & $\begin{array}{l}\text { Model } \\
\text { with } \\
\text { direct } \\
\text { effects }\end{array}$ & $\begin{array}{l}\text { Model } \\
\text { with } \\
\text { inter- } \\
\text { action } \\
\text { effects } \\
\end{array}$ & $\begin{array}{l}\text { Model } \\
\text { with } \\
\text { direct } \\
\text { effects }\end{array}$ & $\begin{array}{l}\text { Model } \\
\text { with } \\
\text { inter- } \\
\text { action } \\
\text { effects }\end{array}$ & $\begin{array}{l}\text { Model } \\
\text { with } \\
\text { direct } \\
\text { effects }\end{array}$ & $\begin{array}{l}\text { Model } \\
\text { with } \\
\text { inter- } \\
\text { action } \\
\text { effects }\end{array}$ & $\begin{array}{l}\text { Model } \\
\text { with } \\
\text { direct } \\
\text { effects }\end{array}$ & $\begin{array}{l}\text { Model } \\
\text { with } \\
\text { inter- } \\
\text { action } \\
\text { effects } \\
\end{array}$ \\
\hline $\begin{array}{l}\text { Agile } \\
\text { methodology } \\
\text { use }\end{array}$ & $0.19^{*}$ & $0.16 \mathrm{~ns}$ & $0.38^{* * * *}$ & $0.32^{* * * *}$ & $0.27^{* * * *}$ & $0.26^{* * * * *}$ & $0.19 *$ & $0.12 \mathrm{~ns}$ \\
\hline Compatibility & $0.22^{*}$ & $0.04 \mathrm{~ns}$ & $0.38 * * * *$ & $0.38 * * * *$ & $0.46^{* * * *}$ & $0.47 * * * *$ & $0.25 *$ & $0.03 \mathrm{~ns}$ \\
\hline $\begin{array}{l}\text { Agile } \\
\text { methodology } \\
\text { use * } \\
\text { compatibility }\end{array}$ & & $0.39 * * *$ & & $0.01 \mathrm{~ns}$ & & $0.03 \mathrm{~ns}$ & & $0.45^{* * *}$ \\
\hline$R^{2}$ & 0.34 & 0.27 & 0.56 & 0.56 & 0.48 & 0.44 & 0.36 & 0.29 \\
\hline
\end{tabular}

Table 7: Summary of hypotheses test

\begin{tabular}{lll}
\hline $\begin{array}{l}\text { Hypothesis } \\
\text { H1. Perceived compatibility has direct or indirect } \\
\text { influence between the agile methodology use and } \\
\text { the cost of the projects. }\end{array}$ & $\begin{array}{l}\text { Result } \\
\beta=0.39,\end{array}$ & $\begin{array}{l}\text { Outcome } \\
\text { Supported }\end{array}$ \\
\hline $\begin{array}{l}\text { H2. Perceived compatibility has direct or indirect } \\
\text { influence between the agile methodology use and }\end{array}$ & $p<0.45$, & Supported \\
the time to complete the projects. & & \\
\hline $\begin{array}{l}\text { H3. Perceived compatibility has direct or indirect } \\
\text { influence between the agile methodology use and } \\
\text { the scope of the projects. }\end{array}$ & $p>0.005$, & $\begin{array}{l}\text { Not sup- } \\
\text { ported }\end{array}$ \\
\hline $\begin{array}{l}\text { H4. Perceived compatibility has direct or indirect } \\
\text { influence between the agile methodology use and } \\
\text { the quality of the projects. }\end{array}$ & $p>0.01$, & $\begin{array}{l}\text { Not sup- } \\
\text { ported }\end{array}$ \\
\hline
\end{tabular}


The agile methodology use of software projects was used in order to determine the time of completion of software projects through the moderating effect of perceived compatibility. Time of completion of software projects referred to the user perception of the extent to which they believed the agile methodology usage would assist them in completing a software project on time (Chow \& Cao, 2008; Moore \& Benbasat, 1991). This means that when IT professionals use the agile methodologies frequently; it could lead to the success of software projects from the perspective of meeting the estimated completion time of the software projects through the moderating effect of perceived compatibility. The implication is that IT professionals prioritise the timely completion of their projects to guarantee their security. It is however possible that IT professionals finish the tasks on time as a result of doing the same job most of the times.

The second factor, cost of the software projects, refers to the user perception of the extent to which they believe the agile methodology usage will assist their cost savings on the projects (Chow \& Cao, 2008; Islam, 2016). This means when IT professionals use the agile methodology frequently and heavily; it could lead to the success of software projects in terms of meeting the estimated budget through the moderating effect of perceived compatibility. Delivering software projects on time is considered as second priority. This might be due to the fact that IT professionals are aware that they get a salary from software projects sales. Therefore, for IT professionals, if the core business is to minimise cost to the company, the use of the agile methodology could accomplish their business goal.

The third factor, scope of the software projects, refers to user perception of the extent to which they believe the agile methodology usage will assist them to meet the scope of the software projects (Chow \& Cao, 2008; Islam, 2016). This means when IT professionals use the agile methodologies frequently and heavily, it could lead to the software projects' success in terms of scope, requirements and specifications of the project being met through the moderating effect of perceived compatibility.

The fourth factor, quality of the software projects, refers to user perception of the extent to which they believe the agile methodology usage will assist them to deliver quality software projects (Chow \& Cao, 2008; Islam, 2016). This means when IT professionals use the agile methodology frequently and heavily, it could lead to the software projects' success in terms of quality, standard and value of the project outcome through the moderating effect of perceived compatibility.

Scope of the projects (meeting all requirements and objectives) and quality (delivering a good product or project outcome) were not considered significant factors in this research study, because the testing results were inconclusive and insignificant to determine the influence agile methodologies could have on these factors.

\section{CONCLUSION}

Most research studies focus on examining the use and adoption of agile methodologies. There is a lack of peer reviewed publications that explain the moderating effects of perceived compatibility towards agile methodology use and perceived success.

This study explored how perceived compatibility impacts agile methodology use and perceived success. The researchers discovered that agile methodology use had significant impact on the time of completion and cost of the software project through the moderating effect of perceived compatibility. 
This means that organisations in South Africa deliver the software projects on time and within the estimated cost and effort. Future studies can carry out the study using longitudinal study instead of cross-sectional study to find out if quality and scope are not significant factors of perceived success in South African projects.

The researchers have used only four variables (cost of the projects, quality of the projects, scope of the projects and time to complete the projects) to conceptualise the agile methodology use outcomes. This study's context was the South African population. Possible points of interest which this study could not cover that may be the subject of future research are: investigating trust, benefit and the influence among the perceived success variables, evaluating the moderating effects of age and gender on the proposed research model, investigating IT professionals who have more than five years of experience, and a specific focus on the Scrum agile methodology as the most adopted agile methodology in South Africa.

\section{References}

Ambler, S. W. (2009). The agile scaling model (ASM): Adapting agile methods for complex environments. Environments, 1-35.

Barclay, D., Higgins, C. \& Thompson, D. (1995). The Partial Least Squares (PLS) approach to causal modelling: Personal computer adoption and use as an illustration. Technology Studies, 2(2), 285-309.

bin Ahlan, A. R. et al. (2013). A coherent framework for understanding critical success factors of ICT project environment. In Research and Innovation in Information Systems (ICRIIS), 2013 International Conference on (pp. 342-347). IEEE.

Boehm, B. \& Turner, R. (2004). Balancing agility and discipline: Evaluating and integrating agile and plan-driven methods. In Software Engineering, 2004. ICSE 2004. Proceedings. 26th International Conference on (pp. 718-719). IEEE. https://doi.org/10.1109/ICSE.2004.1317503

Bossini, J. \& Fernández, A. R. (2013). Using agile methodologies in people management. RPM, 10(1), $33-42$.

Byrne, B. M. (2016). Structural equation modeling with AMOS: Basic concepts, applications, and programming. Routledge.

Cheung, G. W. \& Rensvold, R. B. (2002). Evaluating goodness-of-fit indexes for testing measurement invariance. Structural Equation Modeling, 9(2), 233-255. https://doi.org/10.1207/ S15328007SEM0902_5

Chin, W. W. (1998). The partial least squares approach to structural equation modeling. Modern Methods for Business Research, 295(2), 295-336.

Chow, T. \& Cao, D.-B. (2008). A survey study of critical success factors in agile software projects. Journal of Systems and Software, 81(6), 961-971. https://doi.org/10.1016/j.jss.2007.08. 020

Cockburn, A. \& Highsmith, J. (2001). Agile software development, the people factor. Computer, 34(11), 131-133. https://doi.org/10.1109/2.963450

Cohn, M. (2010). Succeeding with agile: Software development using Scrum. Pearson Education. 
Cohn, M. \& Ford, D. (2003). Introducing an agile process to an organization [software development]. Computer, 36(6), 74-78.

Delone, W. H. \& McLean, E. R. (2003). The DeLone and McLean model of information systems success: A ten-year update. Journal of Management Information Systems, 19(4), 9-30. https: //doi.org/10.1080/07421222.2003.11045748

Dingsøyr, T., Dybå, T. \& Abrahamsson, P. (2008). A preliminary roadmap for empirical research on agile software development. In Agile, 2008. AGILE'08. Conference (pp. 83-94). IEEE. https: //doi.org/10.1109/Agile.2008.50

Dion, P. A. (2008). Interpreting structural equation modeling results: A reply to Martin and Cullen. Journal of Business Ethics, 83(3), 365-368. https://doi.org/10.1007/s10551-007-9634-7

Dybå, T. \& Dingsøyr, T. (2009). What do we know about agile software development? IEEE Software, 26(5), 6-9.

Fornell, C. \& Larcker, D. F. (1981). Structural equation models with unobservable variables and measurement error: Algebra and statistics. Journal of Marketing Research, 382-388. https: //doi.org/10.2307/3150980

Goodhue, D. L. \& Thompson, R. L. (1995). Task-technology fit and individual performance. MIS Quarterly, 213-236. https://doi.org/10.2307/249689

Hartung, J. \& Knapp, G. (2014). Multivariate multiple regression. Last accessed 19 Oct 2018. https://doi.org/10.1002/9781118445112.stat06583

Iivari, J. \& Huisman, M. (2007). The relationship between organizational culture and the deployment of systems development methodologies. MIS Quarterly, 35-58. https://doi.org/10.2307/ 25148780

Islam, A. N. (2016). E-learning system use and its outcomes: Moderating role of perceived compatibility. Telematics and Informatics, 33(1), 48-55. https://doi.org/10.1016/j.tele.2015.06.010

Joseph, N. (2014). A predictive model for information technology project success (Master's thesis, University of Johannesburg, Johannesburg, RSA). Unpublished M.Com thesis.

Larsen, T. J., Sørebø, A. M. \& Sørebø, Ø. (2009). The role of task-technology fit as users' motivation to continue information system use. Computers in Human Behavior, 25(3), 778-784. https: //doi.org/10.1016/j.chb.2009.02.006

Marnewick, C. (2012). A longitudinal analysis of ICT project success. In Proceedings of the South African Institute for Computer Scientists and Information Technologists Conference (pp. 326-334). ACM. https://doi.org/10.1145/2389836.2389875

Misra, S. C., Kumar, V. \& Kumar, U. (2009). Identifying some important success factors in adopting agile software development practices. Journal of Systems and Software, 82(11), 1869-1890. https://doi.org/10.1016/j.jss.2009.05.052

Moore, G. C. \& Benbasat, I. (1991). Development of an instrument to measure the perceptions of adopting an information technology innovation. Information Systems Research, 2(3), 192-222. https://doi.org/10.1287/isre.2.3.192

Nerur, S., Mahapatra, R. \& Mangalaraj, G. (2005). Challenges of migrating to agile methodologies. Communications of the ACM, 48(5), 72-78.

Nunnally, J. (1978). Psychometric theory (2nd). McGraw-Hill. 
Reel, J. S. (1999). Critical success factors in software projects. IEEE Software, (3), 18-23. https: //doi.org/10.1109/52.765782

Segars, A. H. \& Grover, V. (1993). Re-examining perceived ease of use and usefulness: A confirmatory factor analysis. MIS Quarterly, 517-525.

Stankovic, D., Nikolic, V., Djordjevic, M. \& Cao, D.-B. (2013). A survey study of critical success factors in agile software projects in former Yugoslavia IT companies. Journal of Systems and Software, 86(6), 1663-1678.

Straub, D., Boudreau, M.-C. \& Gefen, D. (2004). Validation guidelines for IS positivist research. Communications of the Association for Information systems, 13(1), 24.

Taylor, S. \& Todd, P. A. (1995). Understanding information technology usage: A test of competing models. Information Systems Research, 6(2), 144-176. https://doi.org/10.1287/isre.6.2.144

V. Bullen, C. V. \& F. Rockart, J. F. (1981). A primer on critical success factors. Last accessed 19 Oct 2018. Retrieved from https://dspace.mit.edu/bitstream/handle/1721.1/1988/SWP1220-08368993-CISR069.pdf?sequence $=1$

Venkatesh, V. \& Davis, F. D. (2000). A theoretical extension of the technology acceptance model: Four longitudinal field studies. Management Science, 46(2), 186-204. https://doi.org/10.1287/ mnsc.46.2.186.11926

Venkatesh, V., Morris, M. G., Davis, G. B. \& Davis, F. D. (2003). User acceptance of information technology: Toward a unified view. MIS Quarterly, 425-478. https://doi.org/10.2307/ 30036540

Wold, H. (2006). Partial least squares. In S. Kotz, C. Read, N. Balakrishnan, B. Vidakovic \& N. Johnson (Eds.), Encyclopedia of Statistical Sciences. https://doi.org/10.1002/0471667196.ess1914. pub2 